\title{
Diluted povidone-iodine inhibits tumor growth through apoptosis-induction and suppression of SOD activity
}

\author{
PING SUN $^{1 *}$, JU-MEI ZHAO ${ }^{1,2^{*}}$, ZI-CHAO LUO ${ }^{1}$, PING ZHANG $^{1}$, PING CHEN $^{1}$, \\ XIAO-LONG ZHANG ${ }^{1}$, SHAN LUO ${ }^{1}$, DA-BING YANG ${ }^{1}$, JIAO TAN ${ }^{1}$, YI ZHOU ${ }^{1}$, \\ TAO LIU ${ }^{2}$, YONG-FENG LIU ${ }^{2}$ and YANJUN WEN ${ }^{1}$ \\ ${ }^{1}$ State Key Laboratory of Biotherapy and Cancer Center, West China Hospital, West China \\ Medical School, Chengdu 610041; ${ }^{2}$ Pharmacological Department of Medical College, \\ Yan'an University, Yan'an 716000, P.R. China
}

Received July 22, 2011; Accepted September 9, 2011

DOI: 10.3892/or.2011.1537

\begin{abstract}
Povidone-iodine (PVP-I) is widely used in clinical practice as an antiseptic and flushing agent after surgery to remove a tumor. Our present study was designed to determine whether diluted PVP-I is cytotoxic to colon cancer cells and ascetic tumor cells in vitro and to examine its antitumor effects in vivo. In vitro, CT26 and $\mathrm{H} 22$ cells treated with different concentrations of diluted PVP-I $(0-1.56 \mu \mathrm{g} / \mathrm{ml})$ were analyzed using the mononuclear cell direct cytotoxicity assay (MTT) and a flow cytometry assay. In vivo, Balb/c mice injected in the abdominal cavity with CT26 cells or H22 cells were treated intraperitoneally with different concentrations of PVP-I (0-312.5 $\mu \mathrm{g} / \mathrm{mouse})$, cisplatin $(40 \mathrm{mg} / \mathrm{kg})$ or 5'-FU (30 mg/ $\mathrm{kg}$ ) or left untreated. In vitro, the studies demonstrated the antiproliferative and significant apoptosis-inducing effects of PVP-I in a dose- and time-dependent manner. In vivo, PVP-I significantly repressed the growth of $\mathrm{H} 22$ and CT26 cells in Balb/c mice compared to controls. To explore the mechanism of the antitumor effect of PVP-I, the superoxide dismutase (SOD) activity of ascites extracted from a mouse model and the supernatant of CT26 cells was detected by an SOD kit. The activity of SOD was significantly inhibited in the experimental groups. Taken together, our data suggest that PVP-I exhibits a strong inhibitory effect on tumor growth in colon cancer (CT26) and hepatoma (H22) resulting from apoptosis, both in vitro and in vivo, suggesting a new potential therapeutic approach after tumor excision surgery to colon cancer and hepatoma.
\end{abstract}

Correspondence to: Dr Ju-Mei Zhao, Pharmacological Department of Medical College, Yan'an University, Yan'an 716000, P.R. China

E-mail: jmz2003.stu@163.com

Dr Yanjun Wen, State Key Laboratory of Biotherapy and Cancer Center, West China Hospital, West China Medical School, Chengdu 610041, P.R. China

E-mail: julio_wy@sohu.com

${ }^{*}$ Contributed equally

Key words: povidone-iodine, antitumor, apoptotic, colon carcinoma CT26, ascites hepatoma H22

\section{Introduction}

Colorectal cancer and hepatoma, the most common malignant tumors worldwide, are responsible for a great number of cancer deaths (1-4). Excisional surgery, the most effective therapy in achieving cure, plays an important part in the management of these cancers (5). Owing to port-site metastases, the benefits of laparoscopic surgery which is the primary treatment modality for colorectal cancer are uncertain (6). Balli et al (7) have described a technique for preventing port-site metastases based on their 8-year experience with laparoscopic surgery for colorectal cancer. In this 6 -step technique use of $5 \%$ povidoneiodine (PVP-I) intraluminal irrigation and intraoperative colonoscopy are an important routine (7). Moreover, another laparoscopic experimental study showed that the PVP-I solution resulted in almost zero implantation rate at trocar sites, as compared with other cytotoxic agents (8). These findings suggest that PVP-I probably has anti-tumor activity.

PVP-I, a broad spectrum microbicide against bacteria, virus, fungi and parasites in vitro (9-12), consists of elementary iodine bound to the carrier poly (1-vinyl-2-pyrrolidone) that enhances the solubility and gives a depot of iodine (13). Based on the oxidizing effects of free iodine on $\mathrm{NH}$ - and $\mathrm{SH}-\mathrm{OH}$-groups of amino acids and on double bonds of unsaturated fatty acids, PVP-I showed the ability of non-specifically inducing cell death (14). Previous studies have demonstrated that PVP-I had anti-tumor effects in colon and breast cancer cells in vitro $(13,15)$, and it predominantly induced necrosis of cells in human lung embryonic fibroblasts when in aqueous solutions (13). In addition, PVP-I significantly inhibited tumor implantation in rats dealing with laparoscopy in a mammary adenocarcinoma cell suspension model (16). It has been suggested that PVP-I inhibits malignant pleural mesothelioma (MPM) cell growth via necrosis, with a high production of reactive oxygen intermediates and low mitochondrial membrane permeability (14). However, until now these PVP-I effects have rarely been investigated in colon and in ascites hepatoma. In addition, only a few studies have associated the oxidized effects with PVP-I in cancer therapy.

In this study, we investigated the antitumoral effect of PVP-I on colon carcinoma CT26 cells and hepatoma H22 
cells in Balb/c mice. PVP-I displayed anti-proliferative and apoptotic effects in CT26 and $\mathrm{H} 22$ cells in vitro, and may be a potential therapeutic alternative by increasing the induction of apoptosis which in turn results in significant reduction in tumor weight and volume of ascites. In addition, the results of a superoxide dismutase (SOD) assay suggested that the apoptotic effect of PVP-I in CT26 and H22 cells might be caused by the oxidizing effects of its free iodine.

\section{Materials and methods}

Cell lines and cell culture. CT26 and $\mathrm{H} 22$ cells, purchased from the American Type Culture Collection (ATCC; Rockville, MD, USA), were used in this study. The two cell lines were cultured in RPMI-1640 supplemented with $10 \%$ FBS, $100 \mathrm{IU} / \mathrm{ml}$ penicillin and $100 \mu \mathrm{g} / \mathrm{ml}$ streptomycin in a humidified incubator at $37^{\circ} \mathrm{C}$ and $5 \% \mathrm{CO}_{2}$.

CT26 cellular morphology alterations induced by PVP-I. CT26 cells were plated at the density of $1.5 \times 10^{5}$ cells $/ \mathrm{ml}$ in a 6 -well plate and were incubated overnight in triplicates. Then the cells were treated with $200 \mu \mathrm{l}$ different concentrations of PVP-I $(1.563,0.781,0.391,0.195 \mu \mathrm{g} / \mathrm{ml})$ or normal saline (medium) for $48 \mathrm{~h}$. The morphological changes were examined by inverted phase contrast microscopy (Olympus IX70, Japan, 10x objective) at 24 and $48 \mathrm{~h}$ after incubation with PVP-I.

Cell viability assay. The cytotoxicity of PVP-I in CT26 and $\mathrm{H} 22$ was determined by the 3-(4,5-dimethylthiazol-2-yl)2,5-diphenyl tetrazolium bromide (MTT; Sigma, St. Louis, MO, USA) colorimetric assay. Compactly, about 4,500 CT26 cells $(8,000 \mathrm{H} 22$ cells) were seeded in each well including $200 \mu \mathrm{l}$ fresh medium in a 96-well plate and incubated overnight. MTT solution of $20 \mu 1(5 \mathrm{mg} / \mathrm{ml}$ in PBS) was added into each well at the indicated different time points after adding four different concentrations of PVP-I (1.563, 0.781, 0.391 and $0.195 \mu \mathrm{g} / \mathrm{ml}$ ) into the cultures. Four hours after the addition of the MTT solution, the supernatant liquid was poured out and $150 \mu 1$ of dimethyl sulfoxide (DMSO) was added into every well to adequately dissolve the crystal. Lastly, the spectrometric absorbance of the cells was measured at $570 \mathrm{~nm}$ using a microplate reader (Multiskan, Thermo Scientific, USA). The survival rate of the cells was assessed as percent cell viability of blank group cells using the software Ascent 2.6.

Apoptosis analysis with flow cytometry and the Annexin V-FITC kit. Cell apoptosis was evaluated using flow cytometry and the

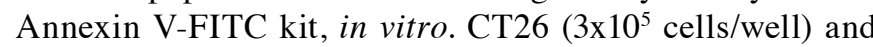
$\mathrm{H} 22$ cells $\left(5 \times 10^{5}\right.$ cells/well) were seeded in a 6 -well plate and treated with different concentrations of PVP-I after incubation for $24 \mathrm{~h}$. Then the cells were exposed to the reagents from the Annexin V-FITC kit (NeoBioscience Ltd., Cambridge, MA, USA) according to the manufacturer's instructions. Finally, the cells were analyzed by flow cytometer. Ascites cells captured from live model mice were treated with the same method. Each experiment was performed at least three times.

Establishment and treatment with $\mathrm{C} 26$ and $\mathrm{H} 22$ tumor model in Balb/c mice. Male Balb/c mice aged 6-8 weeks were purchased from Beijing (Hua Fukang Biotechnology LLC,
Beijing, China) and arranged in good living environment to acclimate for 1-2 weeks before use. All the mice involved in our experiments were raised according to institutional guidelines referring to animal use and care.

About $3 \times 10^{5}$ CT2 6 cells/mouse $\left(5 \times 10^{5} \mathrm{H} 22\right.$ cells/mouse) were inoculated into the right flanks of the model mice which were randomly divided into 6 groups $(6$ mice/group) and received the following treatments (beginning at 4 days after the inoculation): normal saline (NS, $500 \mu \mathrm{l})$, cisplatin $(40 \mathrm{mg} / \mathrm{kg})$ (H22 5'-Fu $30 \mathrm{mg} / \mathrm{kg}$ ), or diluted PVP-I solution (500 $\mu \mathrm{l}, 312.5$, $156.25,78.125$ and $39.06 \mu \mathrm{g} /$ mouse). The treatment schedule contained a single injection per mouse every 2 days and 7 injections in total. At the end of this study, tumor-bearing mice were sacrificed and their organs and tumor tissues were harvested and fixed in neutral-buffered $10 \%$ formaldehyde solution after weighing in order to be used for other indexes (immunohistochemistry, flow cytometry) analysis.

Quantitative detection of apoptosis. Tumor cell species were prepared as mentioned above. The location of apoptotic cells in the tumor tissue from mice model were detected by using the In Situ Cell Death Detection kit (DeadEnd Fluorometric TUNEL System; Promega, Madison, WI, USA) according to the manufacturer's instructions. Four equal-sized fields were selected randomly and analyzed in the tissue sections. The apoptotic index (AI) was calculated by the formula AI $(\%)=$ $100 \mathrm{x}$ apoptotic cells/total tumor cells.

Activity of SOD analysis. To study one of the probable mechanisms of PVP-I-induced apoptosis in tumor cells, the activity of SOD was detected with a colorimetric method. CT26 cells $\left(1.5 \times 10^{5} \mathrm{cells} / \mathrm{ml}\right)$ were seeded in a 6 -well plate and incubated for $24 \mathrm{~h}$. Four different concentrations PVP-I were added in to the 6-well plate and the cells were continuously incubated for $24 \mathrm{~h}$. Next, cells were harvested and stained according to the instruction of the SOD kit [Nanjing Jiancheng Biotechnology Institute SOD kit (detect total), Nanjing, China]. The activity of SOD was assessed by an ultraviolet spectrophotometer (SmartSpec 3000, Bio-Rad, USA). The activity of H22 cells from the ascites of the experimental mice was detected and analyzed in a similar manner to CT26 cells.

Estimate of potential adverse effects. In order to appraise the potential adverse effects or toxicity of PVP-I in the mice during the treatment, gross surveys such as weight loss, ruffling of fur, lifespan, behavior and feeding were monitored and studied.

Statistical analysis. All the data were analyzed by the statistical software SPSS16.0. The Student's t-test was used to assess if the differences between the test and control groups were significant. Differences between treatments or ranks were considered to be significant at $\mathrm{P} \leq 0.05$. All data are expressed as means \pm SD from at least three independent experiments.

\section{Results}

CT26 cellular morphology alterations induced by PVP-I. The number of CT26 cells decreased after the treatment with 1.56 , 0.781 or $0.391 \mu \mathrm{g} / \mathrm{ml}$ PVP-I for $24 \mathrm{~h}$, indicating that PVP-I is cytotoxic to cells; the decrease at the $0.195 \mu \mathrm{g} / \mathrm{ml}$ PVP-I 


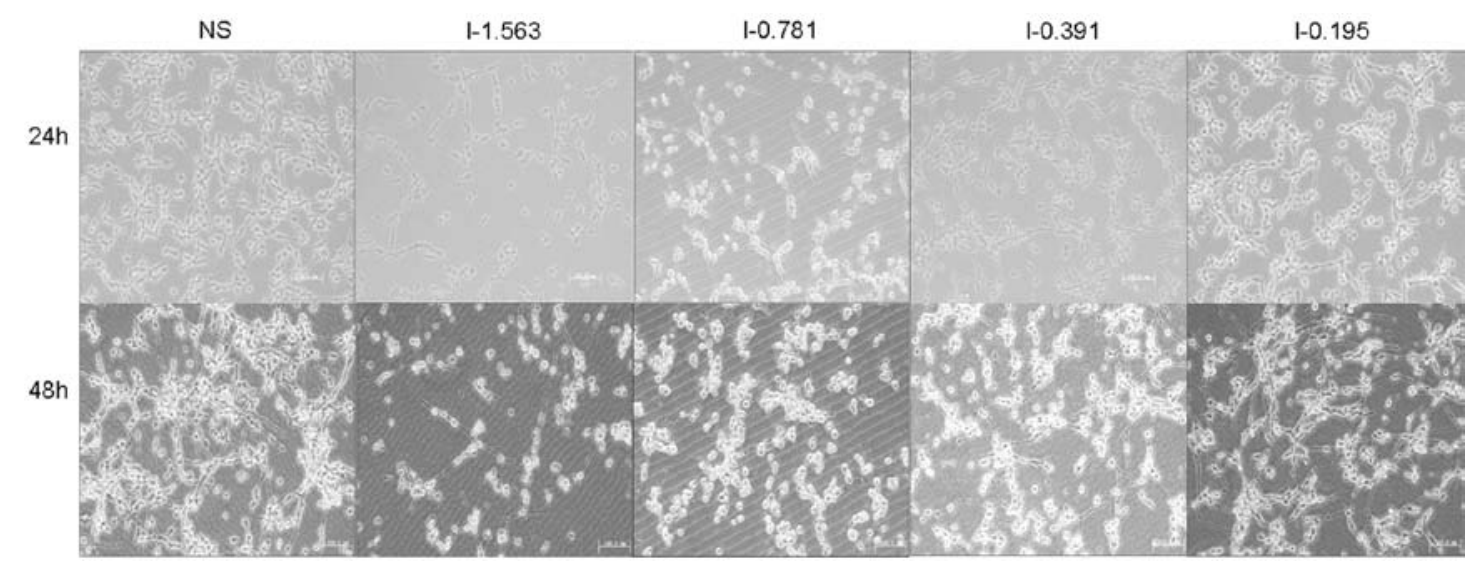

Figure 1. PVP-I induces alterations in cellular morphology in CT26 cells. CT26 cells were plated at density of $1.5 \times 10^{5}$ cells $/ \mathrm{ml}$ in a 6 -well plate and were treated with different concentrations of PVP-I $(1.563,0.781,0.391,0.195 \mu \mathrm{g} / \mathrm{ml})$ for $48 \mathrm{~h}$ in triplicates. The alterations in cellular morphology were examined by inverted phase contrast microscopy (10x objective) at 24 and $48 \mathrm{~h}$. Round-shaped and floated cells imply cell death.

A

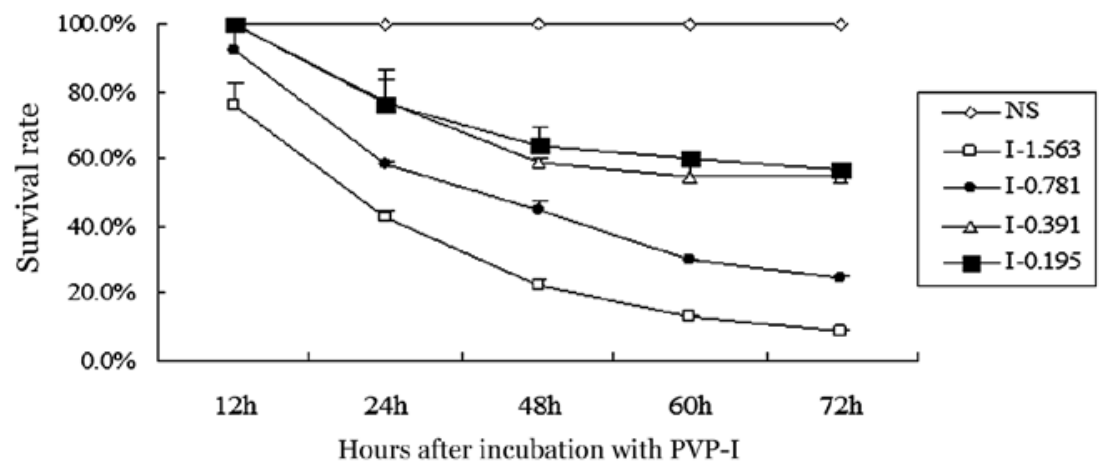

B

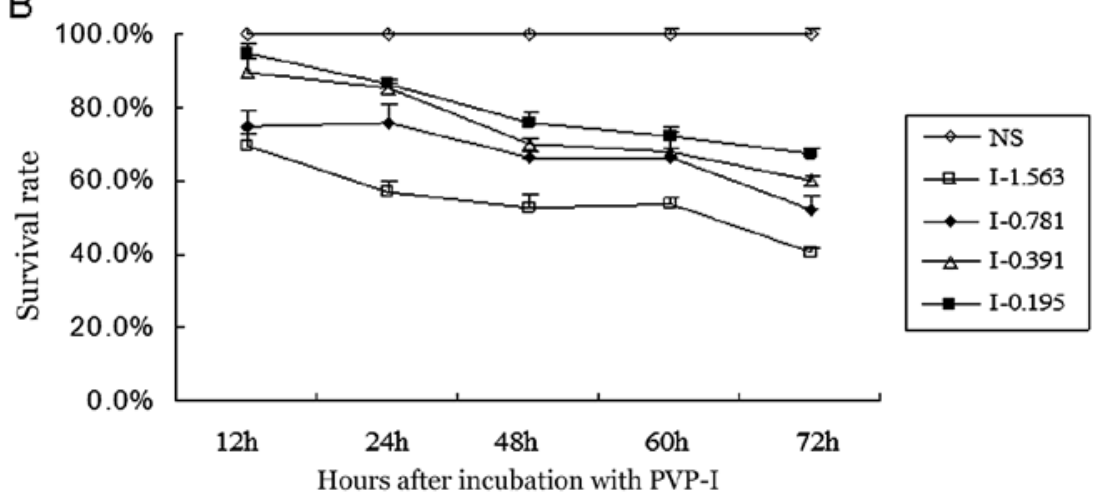

Figure 2. MTT assay of cell viability of CT26 and H22 cells treated with different concentrations of PVP-I. CT26 and H22 cells were treated with different concentrations of PVP-I $(1.563,0.781,0.391$ and $0.195 \mu \mathrm{g} / \mathrm{ml})$ for 12, 24, 48, 60 and $72 \mathrm{~h}$, respectively. (A) MTT assay of CT26 cells. (B) MTT assay of H22 cells. Absorbance values obtained with untreated cells (NS) were taken as 100\% cell growth. The results showed that PVP-I inhibited the growth of CT26 cells and $\mathrm{H} 22$ cells in a dose- and time-dependent manner. The data represent mean $\pm \mathrm{SD}$ of three independent experiments.

concentration was not significant. Cells treated with PVP-I rounded up and detached from the substratum, suggesting cell death (Fig. 1). There were no significant differences between the cell number of the groups treated with the same PVP-I concentration for $24 \mathrm{~h}$ and $48 \mathrm{~h}$.

Antiproliferative and apoptosis-inducing effects of PVP-I. The results of the previous experiments in vitro showed that PVP-I has a significant anti-tumor effect. Based on the results of the MTT assay (Fig. 2A), PVP-I inhibited the growth of carcinoma cells even at low dose (I-0.195 group). The higher the concentration of PVP-I was the lower the rate of cell survival was at the same time point. The I-1.563 group showed the highest inhibition rate compared with the other groups. PVP-I also induced a growth inhibitory effect on $\mathrm{H} 22$ cells as assessed by the MTT assay (Fig. 2B). In CT26 and $\mathrm{H} 22$ cells, growth inhibition was induced by PVP-I in a doseand time-dependent manner. 


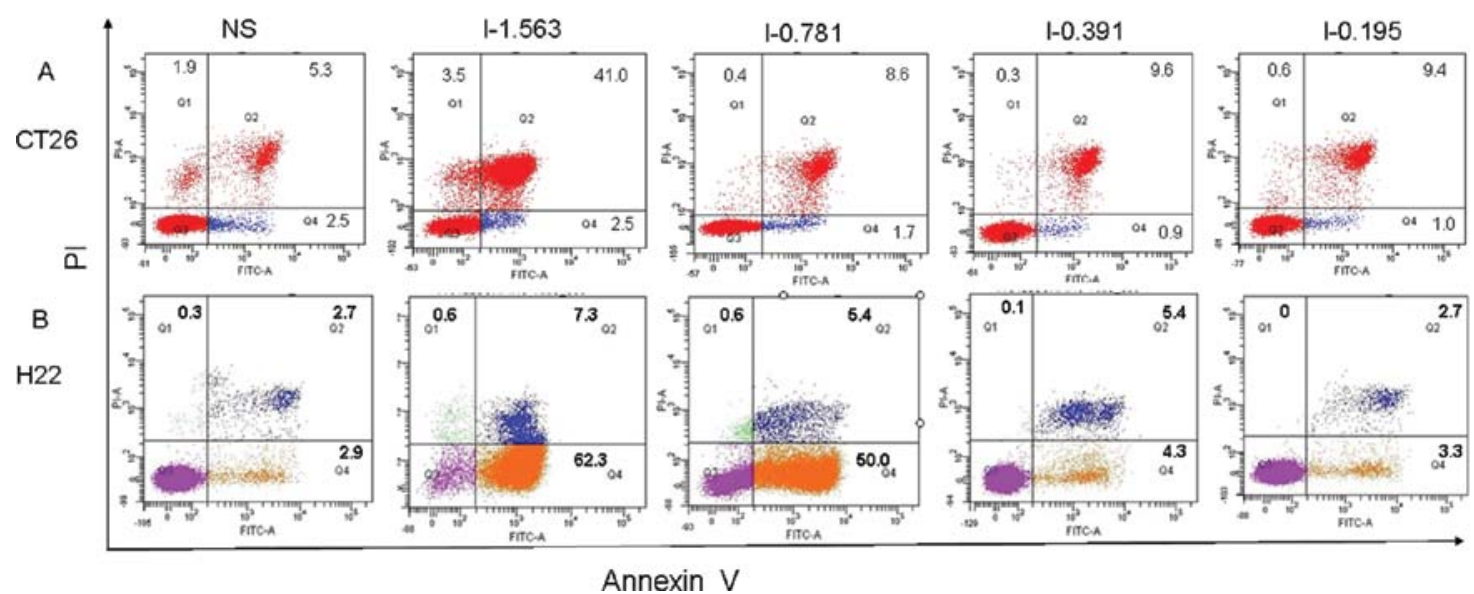

Figure 3. PVP-I induces apoptosis in CT26 and H22 cells as detected by flow cytometry. Cells were treated with various concentrations of PVP-I (1.563, 0.781 , 0.391 and $0.195 \mu \mathrm{g} / \mathrm{ml}$ ) or normal saline medium (NS) for $48 \mathrm{~h}$ and then stained with propidium iodide (PI) and Annexin V-FITC. The apoptotic cells were measured by flow cytometry. The results revealed that the highest concentration group significantly increased the number of apoptotic tumor cells compared with NS. The data represent mean \pm SD of three independent experiments.

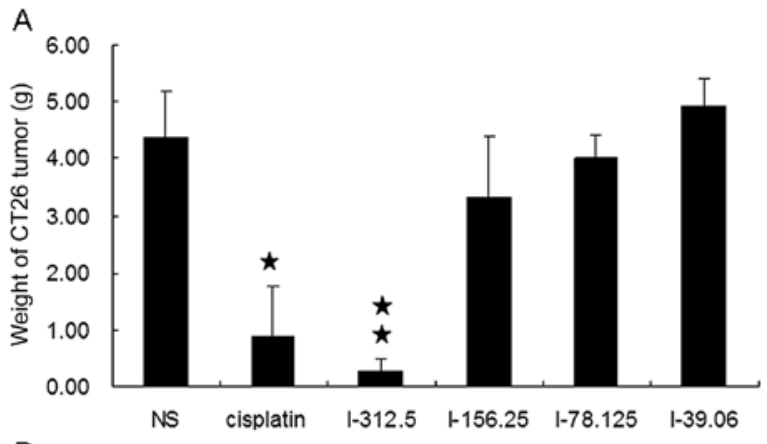

B

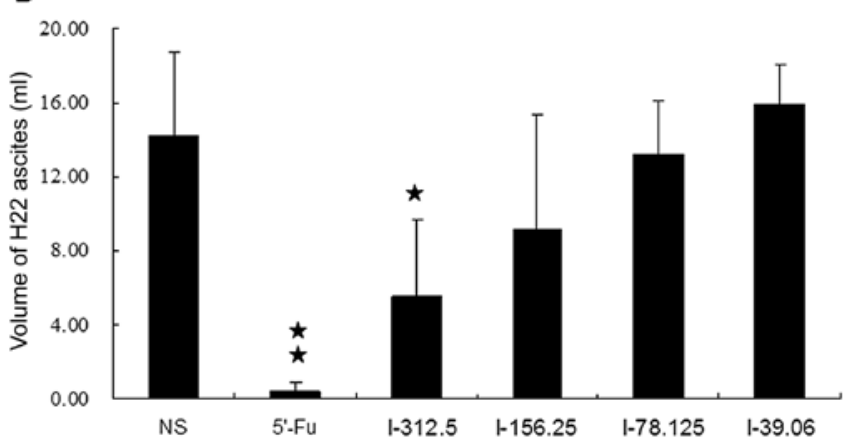

Figure 4. Tumor suppression induced by PVP-I in Balb/c mice. Tumor bearing mice (6 per group) were treated with i.p. administration of normal saline (NS), cisplatin ( $40 \mathrm{mg} / \mathrm{kg}$ ) or 5 '- $\mathrm{Fu}(30 \mathrm{mg} / \mathrm{kg}$ ), PVP-I (39.06-312.5 $\mu \mathrm{g})$ on Days 4, 6, 8, 10, 12, 14, 16 after tumor cell inoculation. (A) Suppression of CT26 tumor growth in mice. The I-312.5 group showed significant tumor growth inhibition vs. the NS control $(\mathrm{P}<0.01)$ and other low dose groups $(\mathrm{P}<0.01)$. (B) Suppression of $\mathrm{H} 22$ ascites tumor growth in mice. The volume of H22 ascites in the I-312.5 group was significantly inhibited compared to the NS control or the other groups $(\mathrm{P}<0.05)$. Column, average tumor weight (volume); error bars, $\pm \mathrm{SD} .{ }^{*} \mathrm{P}<0.05 ;{ }^{* *} \mathrm{P}<0.01$.

To further determine whether the PVP-I-induced cytotoxicity is associated with apoptosis, a flow cytometry assay was performed. The results of flow cytometry with Annexin V assay demonstrated that PVP-I could induce the apoptosis of CT26 cells and the highest dosage group displayed a remarkable ability of inducing apoptosis of tumor cells (43.5\%), comparing with other groups (Fig. 3A). Similar results were detected when $\mathrm{H} 22$ cells were incubated with different concentrations of PVP-I $(0-1.56 \mu \mathrm{g} / \mathrm{ml})$. After $48 \mathrm{~h}$ treatment with various concentrations of PVP-I, we observed the occurrence of apoptosis in $\mathrm{H} 22$ cells, especially at the high-dose PVP-I (Fig. 3B). However, the sensitivities of the CT26 cell line and H22 cell line to PVP-I were quite different. For instance, CT26 apoptotic cells were mainly in the early stage $(41.0 \%)$ while $\mathrm{H} 22$ apoptoitic cells were mainly in the late stage $(62.3 \%)$ in the I-1.563 group.

Tumor growth inhibition induced by PVP-I. To investigate the anti-tumor effect in vivo, CT26 $\left(3 \times 10^{5}\right.$ cells) or H22 $\left(5 \times 10^{5}\right.$ cells) cells were i.p. injected in Balb/c mice. After treatment with different concentrations of PVP-I, the mice were sacrificed and the CT26 tumor or the $\mathrm{H} 22$ ascites were collected. In the CT26 model (Fig. 4A), the weight of the tumor in the I-312.5 group was much lower than any other groups (even the positive control treated with cisplatin) with a $93 \%$ inhibition rate. However, the other groups did not show an apparent anti-tumor effect. In the H22 model (Fig. 4B), the volume of $\mathrm{H} 22$ ascites in I-312.5 group was $8 \mathrm{ml}$ less than that in the NS control group $(\mathrm{P}<0.05)$ with a $61 \%$ inhibition rate. There was no difference between the NS group and the low dose of PVP-I groups.

Therapeutic effects on apoptosis. In order to determine whether apoptosis was indeed the mechanism by which an iodophor has anti-tumor effects in vivo, the TUNEL assay was performed. The CT26 tumors resected from the Balb/c mice after complete treatment were subjected to TUNEL assays. The I-312.5 group (apoptotic index, 19.1) and the I-156.2 group (apoptotic index, 8.6) had significant effect on the apoptotic rate of CT26 tumor cells, because an apparent increase in the number of apoptotic cells was observed within the tumors of the two groups (Fig. 5).

Activity of SOD analysis. In order to verify our hypothesis about the mechanism of the cytotoxicity of PVP-I in tumor cells, the activity of SOD was examined by the SOD kit. The SOD assay revealed that PVP-I induced cell death due to the 

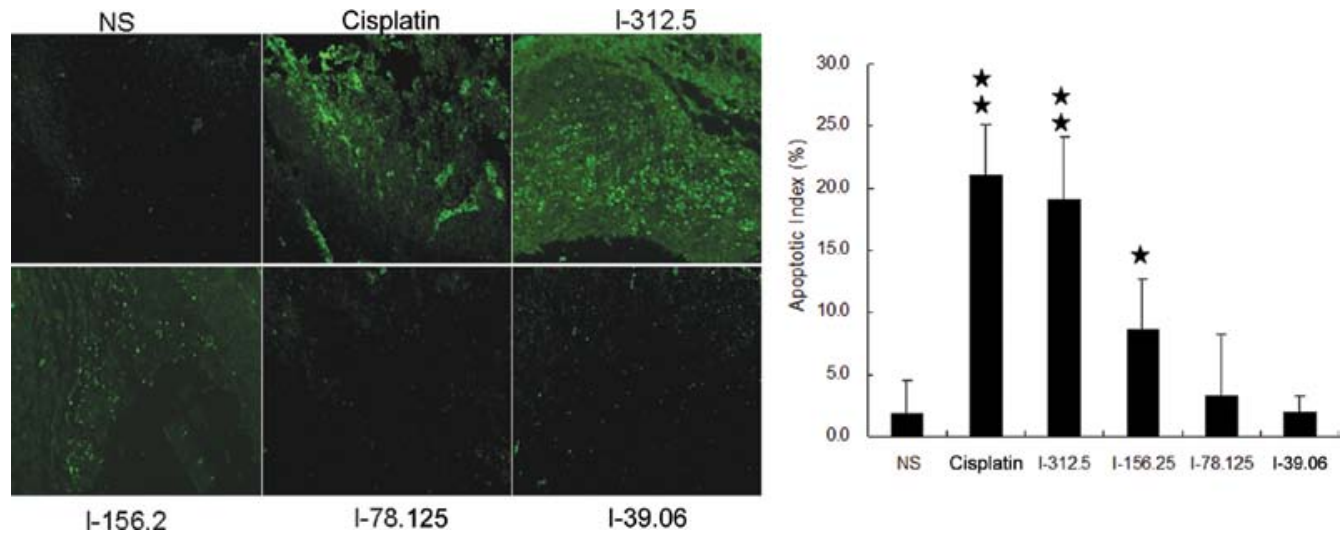

Figure 5. Apoptotic tumor cells within CT26 tumor tissues were detected by the TUNEL assay. An obvious increase in the number of apoptotic cells and the apoptotic index was observed within the tumor tissues treated with cisplatin and PVP-I (312.5 $\mu \mathrm{g} / \mathrm{mouse})$ compared with NS control and other dose groups $(\mathrm{P}<0.05)$. Data represent the mean apoptotic index \pm SD of tumor cells. ${ }^{*} \mathrm{P}<0.05 ;{ }^{* *} \mathrm{P}<0.01$.

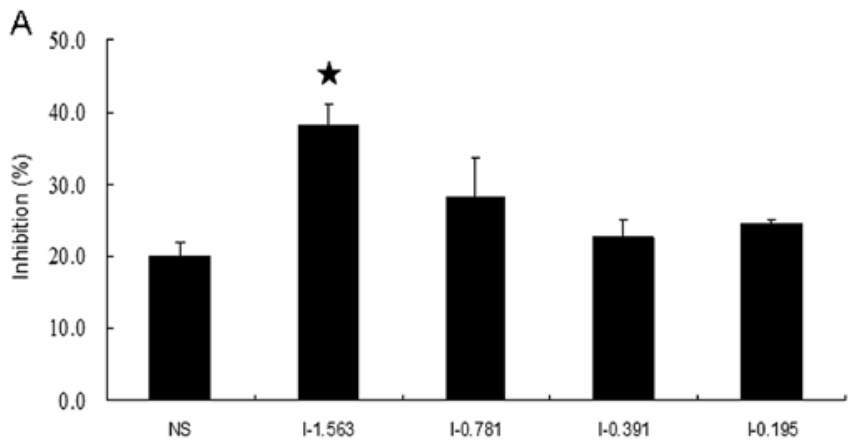

B

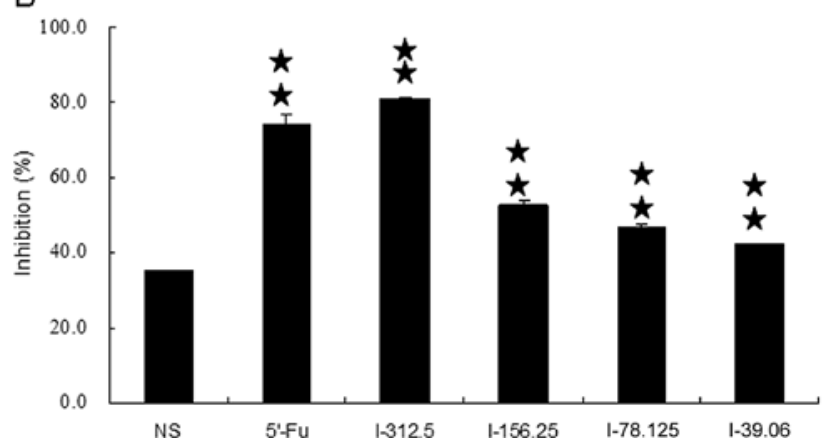

Figure 6. Inhibition on the activity of SOD induced by PVP-I. (A) The activity of SOD assay on CT26 culturing suspension after incubated with PVP-I. CT26 cells $\left(1.5 \times 10^{5}\right.$ cells $\left./ \mathrm{ml}\right)$ were plated in a 6 -well plate and treated with different concentration of PVP-I or normal saline for $24 \mathrm{~h}$. Then the culture supernatant was collected for SOD assay. The activity of SOD in I-1.563 group was obviously inhibited compared with the control group $(\mathrm{P}<0.05)$. (B) The activity of SOD assay on $\mathrm{H} 22$ ascites obtained from the experimental mice. The results showed that the PVP-I inhibited the activity of SOD $(\mathrm{P}<0.01)$, while the high-dose (I-312.5 group) gave a significant inhibition. The bar represents the mean $\pm \mathrm{SD}$. ${ }^{*} \mathrm{P}<0.05 ;{ }^{* *} \mathrm{P}<0.01$.

oxidizing effects of free iodine on $\mathrm{SH}-\mathrm{OH}$-and $\mathrm{NH}$-groups of amino acids and on double bonds of unsaturated fatty acids (14). In vitro, CT26 cells $\left(1.5 \times 10^{5}\right.$ cells $\left./ \mathrm{ml}\right)$ plated in a 6 -well plate were treated with different concentrations of PVP-I, and the culture supernatant was collected for the SOD assay. The results (Fig. 6A) suggest that the I-1.563 group significantly inhibited cell growth compared with the other groups $(\mathrm{P}<0.05)$. In vivo, the $\mathrm{H} 22$ ascites obtained from mice of different groups were used for the SOD assay. The results revealed that the
I-312.5 group inhibition of SOD activity in the H22 cells was greater than that in the positive control group treated with 5'-FU (Fig. 6B), and the percent inhibition rate of PVP-I was dependent on its concentration.

Evaluation of side-effects. In order to evaluate the possible adverse effects of treatments, the weights of mice were weighed every 3 days throughout the whole experiment and were considered as a variable for evaluation of systemic wellbeing or cachexia. No drastic differences in weights were found among the 5 groups in the CT26 model. However, in the $\mathrm{H} 22$ model, the weights increased as ascites increased especially in the low dose groups. No adverse effects in other gross measures such as ruffling of fur, behavior, feeding, or toxic death were observed in the test groups. However, the chemotherapy may not be entirely innocuous.

\section{Discussion}

PVP-I, a combination of molecular iodine and polyvinylpyrrolidone, has replaced the solution (tincture) of iodine widely used in clinical practice (17). PVP-I is an example of an iodophor that acts as a conservator of free active iodine (18). It has been used in hand disinfection, skin preparation and antiseptic irrigation for many years owing to the effective and wide antimicrobial activity $(19,20)$. PVP-I should be developed for cancer prevention and eradication (21). PVP-I is effective in eliminating the abnormal supplement of the maturation promoting system causing an inconvertible duplication of mitosis leading to cancer development (22-24). It is well-documented that molecular iodine $\left(\mathrm{I}_{2}\right)$ has a potent antitumor effect on mammary cancer in rats via regulating the cell oxidative environment (25). A gene array study showed that PVP-I inhibits breast cancer (MCF-7) through modulation of the estrogen pathway (26). Moreover, Shrivastava et al (27) have showed that iodine induced human breast cancer cell (MCF-7) death through activating a caspase-independent and mitochondria-mediated apoptotic pathway.

In our study, PVP-I showed cytotoxic effects in cultured CT26 and H22 cells using the MTT assay (Fig. 2), and the cytotoxic effects showed a dependence on the concentration of the PVP-I treatment in the cells. In vitro, the apoptotic percent 
of CT26 cells (H22 cells) treated with PVP-I were measured by flow cytometry, and the results showed that PVP-I can induce apoptosis of CT26 cells (H22 cells), in a dose-denpendent manner (Fig. 3). This result may explain why PVP-I is used as cytotoxic agents for prevention of port-site metastases after excisional surgery.

In vivo, the CT26 model showed that PVP-I inhibited the tumor growth and the percent inhibition was up to $93 \%$ when the dose was $312.5 \mu \mathrm{g} /$ mouse (Fig. 4A). In the H22 model, the volume of the ascites in the high-dose groups also suggested that PVP-I inhibited ascites tumor growth (Fig. 4B). Previous studies have shown that molecular iodine inhibited breast tumor growth in rats through caspase-independent apoptosis (27) and that in thyroid cancer cells by regulating the expression of the MAPK-related p53, p21, and Bcl-xL (28). It has also been suggested that iodine inhibition of N-methyl$\mathrm{N}$-nitrosourea-induced mammary carcinogenesis may occur via regulation of the cell oxidative environment (25). In our study, the TUNEL assays of CT26 tumor tissues suggest that PVP-I reduced the growths of those tumors via inducing the apoptosis of tumor cells (Fig. 5).

Previous studies have demonstrated that free radicals, reactive oxygen species (ROS) with resulting oxidative stress, play a critical role in apoptosis (29). SOD can block or delay apoptosis via clearing the superoxide anion $\left(\mathrm{O}_{2}{ }^{\circ}\right)$ which promotes the cell generating oxidative stress (30). Therefore, the activity of SOD may be an index of its connection to apoptosis. In our study, the inhibition of the activity of SOD in $\mathrm{H} 22$ ascites treated with different doses of PVP-I showed that inhibition activity of SOD was concentration-dependent (Fig. 6B), which suggests that PVP-I induced the apoptosis by inhibiting the activity of SOD. This was also demonstrated in the inhibition of the activity of SOD in CT26 cells treated with PVP-I in vitro (Fig. 6A).

In conclusion, our data suggest that diluted PVP-I inhibited CT26 and $\mathrm{H} 22$ tumor growth via inducing the apoptosis in a dose-dependent manner. Inhibition of SOD activity by PVP-I may explain the apoptosis. Furthermore, as the PVP-I has been licensed for human use, the diluted PVP-I may provide a potential application of therapy of CT26 and $\mathrm{H} 22$ tumors in the clinic.

\section{Acknowledgements}

The study was supported by the Scientific Research Foundation of Shaanxi Provincial Health Bureau (grant no, 2008H039) and the Scientific Research Foundation of Yan'an Shaanxi province in 2008 (grant no, 2008ks-30).

\section{References}

1. Jemal A, Siegel R, Ward E, et al: Cancer statistics, 2008. CA Cancer J Clin 58: 71-96, 2008

2. Llovet JM, Burroughs A and Bruix J: Hepatocellular carcinoma. Lancet 362: 1907-1917, 2003.

3. Bruix J and Llovet JM: Prognostic prediction and treatment strategy in hepatocellular carcinoma. Hepatology 35: 519-524, 2002.

4. Blum HE: Hepatocellular carcinoma: therapy and prevention. World J Gastroenterol 11: 7391-7400, 2005.
5. Gilson SD: Principles of surgery for cancer palliation and treatment of metastases. Clin Tech Small Anim Pract 13: 65-69, 1998.

6. Bertagnolli MM and DeCosse JJ: Laparoscopic colon resection for cancer - an unfavorable view. Adv Surg 29: 155-164, 1996.

7. Balli JE, Franklin ME, Almeida JA, Glass JL, Diaz JA and Reymond M: How to prevent port-site metastases in laparoscopic colorectal surgery. Surg Endosc 14: 1034-1036, 2000.

8. Neuhaus SJ, Watson DI, Ellis T, Dodd T, Rofe AM and Jamieson GG: Efficacy of cytotoxic agents for the prevention of laparoscopic port-site metastases. Arch Surg 133: 762-766, 1998.

9. Shiraishi T, Oka R and Nakagawa Y: Pharmaceutical and bacteriological study on povidone-iodine sugar ointment. Dermatology 195 (Suppl 2): S100-S103, 1997.

10. Kawana R, Kitamura T, Nakagomi O, et al: Inactivation of human viruses by povidone-iodine in comparison with other antiseptics. Dermatology 195 (Suppl 2): S29-S35, 1997.

11. Bonowitz A, Schaller M, Laude J, Reimer K and Korting HC: Comparative therapeutic and toxic effects of different povidone iodine (PVP-I) formulations in a model of oral candidosis based on in vitro reconstituted epithelium. J Drug Target 9: 75-83, 2001.

12. Konig B, Reimer K, Fleischer W and Konig W: Effects of Betaisodona on parameters of host defense. Dermatology 195 (Suppl 2): S42-S48, 1997.

13. Wutzler P, Sauerbrei A, Klocking R, Brogmann B and Reimer K: Virucidal activity and cytotoxicity of the liposomal formulation of povidone-iodine. Antiviral Res 54: 89-97, 2002.

14. Opitz I, Sigrist B, Hillinger S, et al: Taurolidine and povidoneiodine induce different types of cell death in malignant pleural mesothelioma. Lung Cancer 56: 327-336, 2007.

15. Basha G, Penninckx F and Yap P: Influence of blood components and faeces on the in vitro cancericidal activity of povidoneiodine. Br J Surg 85: 534-537, 1998.

16. Neuhaus SJ, Watson DI, Ellis T, Rofe AM and Jamieson GG: Influence of cytotoxic agents on intraperitoneal tumor implantation after laparoscopy. Dis Colon Rectum 42: 10-15, 1999.

17. Durani P and Leaper D: Povidone-iodine: use in hand disinfection, skin preparation and antiseptic irrigation. Int Wound J 5: 376-387, 2008.

18. McDonnell G and Russell AD: Antiseptics and disinfectants: activity, action, and resistance. Clin Microbiol Rev 12: 147-179, 1999.

19. Zamora JL: Chemical and microbiologic characteristics and toxicity of povidone-iodine solutions. Am J Surg 151: 400-406, 1986.

20. Bryan JL, Cohran J and Larson EL: Hand washing: a ritual revisited. Crit Care Nurs Clin North Am 7: 617-625, 1995.

21. Hirata $\mathrm{Y}$ and Hirata S: The use of ionized iodine for cancer prevention and eradication. Med Hypotheses 58: 254-256, 2002.

22. Hirata Y: An enzymatic effect for cancer prevention and eradication. Med Hypotheses 45: 465-467, 1995.

23. Hirata Y: Duplication mitosis in epithelio-glandular tissue. Med Hypotheses 37: 44-46, 1992.

24. Hirata Y: Hetero-duplication type of cancerous mitosis. Med Hypotheses 41: 509-512, 1993.

25. Garcia-Solis P, Alfaro Y, Anguiano B, et al: Inhibition of N-methyl-N-nitrosourea-induced mammary carcinogenesis by molecular iodine $\left(\mathrm{I}_{2}\right)$ but not by iodide $\left(\mathrm{I}^{-}\right)$treatment Evidence that $\mathrm{I}_{2}$ prevents cancer promotion. Mol Cell Endocrinol 236: 49-57, 2005.

26. Stoddard FR II, Brooks AD, Eskin BA and Johannes GJ: Iodine alters gene expression in the MCF7 breast cancer cell line: evidence for an anti-estrogen effect of iodine. Int J Med Sci 5: 189-196, 2008.

27. Shrivastava A, Tiwari M, Sinha RA, et al: Molecular iodine induces caspase-independent apoptosis in human breast carcinoma cells involving the mitochondria-mediated pathway. J Biol Chem 281: 19762-19771, 2006.

28. Liu XH, Chen GG, Vlantis AC, Tse GM and van Hasselt CA: Iodine induces apoptosis via regulating MAPKs-related p53, p21, and Bcl-xL in thyroid cancer cells. Mol Cell Endocrinol 320: $128-135,2010$

29. Kannan K and Jain SK: Oxidative stress and apoptosis. Pathophysiology 7: 153-163, 2000.

30. Haddad JJ: Redox and oxidant-mediated regulation of apoptosis signaling pathways: immuno-pharmaco-redox conception of oxidative siege versus cell death commitment. Int Immunopharmacol 4: 475-493, 2004. 